Esta publicación cientifica en formato digital es continuidad de la revista impresa ISSN-Versión Impresa 0798-1406 / ISSN-Versión on line 2542-3185Depósito legal pp
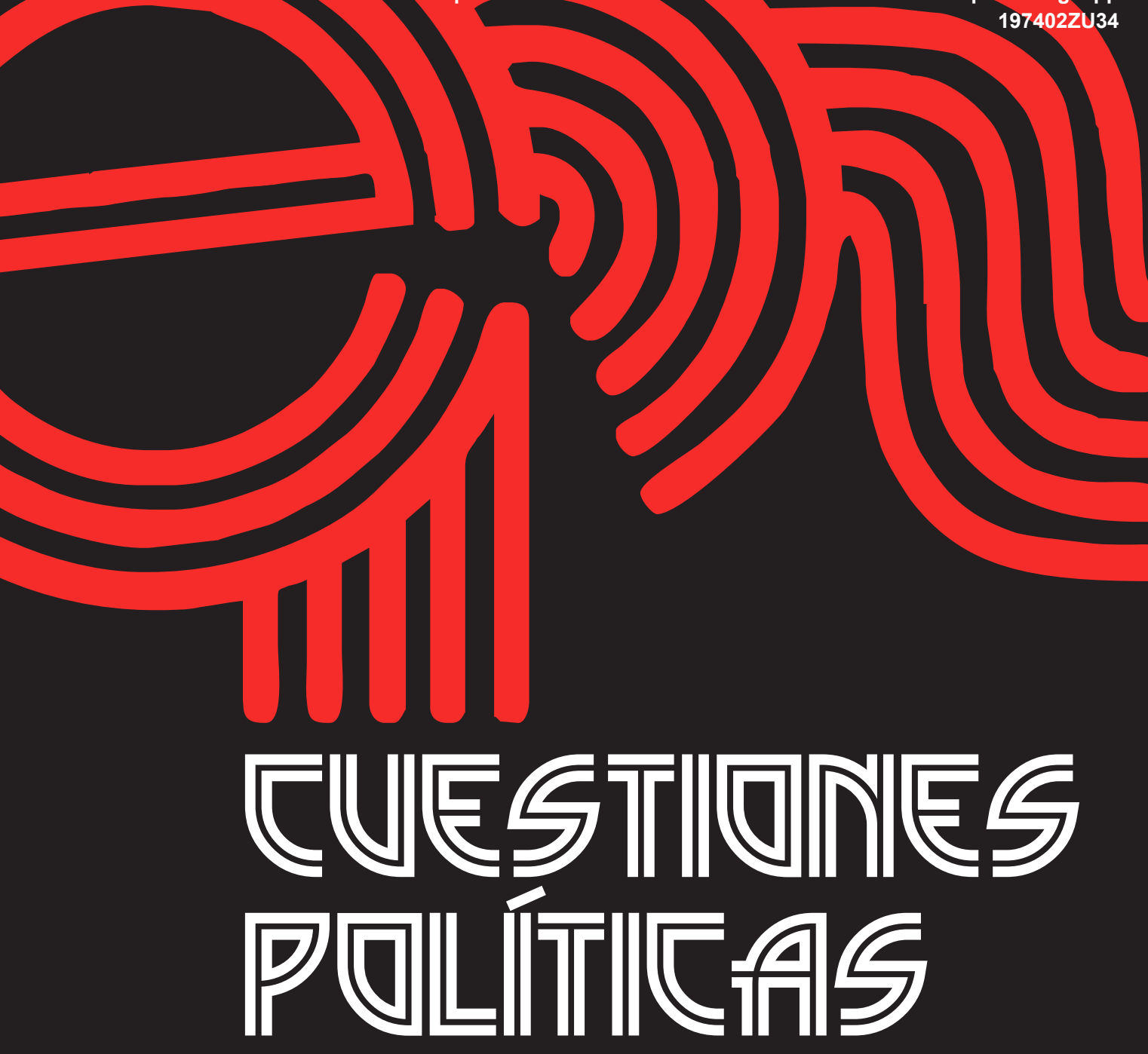

Instituto de Estudios Políticos y Derecho Público "Dr. Humberto J. La Roche" de la Facultad de Ciencias Jurídicas y Políticas de la Universidad del Zulia Maracaibo, Venezuela
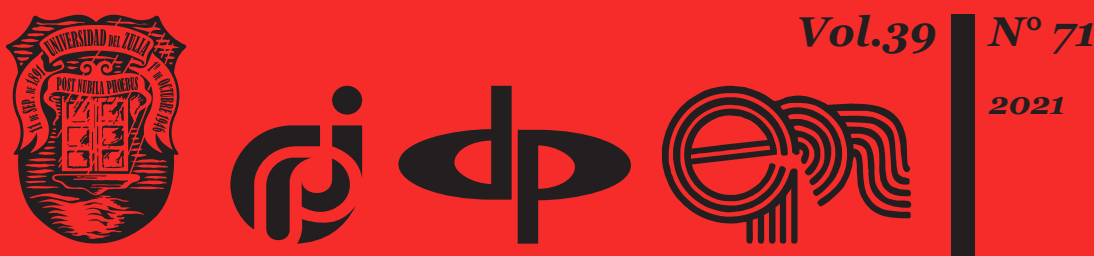


\title{
State policy for the development of multimodal transportation by clean and energy efficient motor transport
}

\author{
DOI: https://doi.org/10.46398/cuestpol.3971.54
}

\author{
Oleksandr Datsii * \\ Nataliia Levchenko ** \\ Ganna Shyshkanova *** \\ Oleg Platonov ***** \\ Viktoriia Zalizniuk $* * * * *$
}

\section{Abstract}

The article substantiates the need for the Government of Ukraine to form a state policy for the development of multimodal transportation by clean and energy efficient vehicles, which will accelerate Ukraine's integration into the European and world space. The main strategic priorities for the development of multimodal transport, provided by the National Transport Strategy of Ukraine until 2030, are studied and its gaps are emphasized. The state policies of the developed countries concerning popularization of multimodal freight transportations by electric cars are considered and their comparative analysis is carried out. During the study, the following methods were used: comparative analysis, strategic analysis, - GAP-analysis, abstract-logical. It is substantiated that the formation of the balanced state policy for the development of clean and energy efficient multimodal transportation should be carried out with a presize definition of the stage and sequence of actions, ie in accordance with a guide for the state policy formation. The present paper is dedicated to the development of the guide. The author's guide is aimed at protecting the environment and ensuring the interests of present and future generations in a favorable environmentally friendly living conditions.

Keywords: public policies; multimodal transport; clean vehicles; energy efficiency; sustainable development.

\footnotetext{
* Interregional Academy of Personnel Management, Kyiv, Ukraine. ORCID ID: https://orcid.org/oooo0002-7436-3264

*** National University "Zaporizhzhia Polytechnic", Ukraine. ORCID ID: https://orcid.org/oooo-ooo23283-6924

*** National University "Zaporizhzhia Polytechnic", Ukraine. ORCID ID: https://orcid.org/oooo-ooo20336-2803

***** Interregional Academy of Personnel Management, Kyiv, Ukraine. ORCID ID: https://orcid.org/oooo0002-3059-5389

***** Kyiv national trade and economy university, Ukraine. ORCID ID: https://orcid.org//oooo-ooo27014-0207 


\section{Política estatal para el desarrollo del transporte multimodal mediante transporte de motor limpio y eficiente energéticamente}

\section{Resumen}

El artículo estudia la necesidad de que el Gobierno de Ucrania forme una política para el desarrollo del transporte multimodal mediante vehículos limpios y energéticamente eficientes, que acelerará la integración de Ucrania en el espacio europeo y mundial. Se estudian las principales prioridades estratégicas para el desarrollo del transporte multimodal, previstas por la Estrategia Nacional de Transporte de Ucrania hasta 2030 y se enfatizan sus lagunas. Se consideran las políticas estatales de los países desarrollados en cuanto a la popularización de los transportes multimodales de carga por carros eléctricos y se realiza un análisis comparativo. En el curso del estudio, se utilizaron los siguientes métodos: análisis comparativo, análisis estratégico, análisis GAP, abstracto-lógico. Se concluye que la formación de la política estatal equilibrada para el desarrollo de un transporte multimodal limpio y energéticamente eficiente debe realizarse con una definición preestablecida de la etapa y secuencia de acciones, es decir, de acuerdo con una guía para la formación de la política estatal. El presente trabajo está dedicado al desarrollo de la guía. Esta guia tiene como objetivo proteger el medio ambiente y velar por los intereses de las generaciones presentes y futuras en unas condiciones de vida favorables con el medio ambiente.

Palabras clave: políticas públicas; transporte multimodal; vehículos limpios; eficiencia energética; desarrollo sostenible.

\section{Introduction}

Ensuring Ukraine's integration into the European and world economic systems is to some extent marked by the development of multimodal transport, the pace of which is determined by Ukrainian carriers' compliance with the European Climate Law (European Commission, in: https://ec.europa.eu/clima/policies/eu-climate- action / law_en, 2021), the new transport strategy of the European Commission and the Action Plan for the transformation by 2050 of the European transport system to a smart, competitive, sustainable and safe transport system with a reduction of carbon emissions by cars up to 90\% compared to 1990 levels., in order to accelerate the development of multimodal transport and, consequently, Ukraine's integration into the European and world space, the Government of Ukraine urgently needs to take a number of measures, including the 
development of a state policy for the development of multimodal transport by clean and energy efficient vehicles. etc. terraces of present and future generations in a favorable environment. Instead, this is possible only with a clear understanding of the challenges facing Ukrainian carriers, their critical understanding and understanding of the possibilities of their prevention or minimization.

Consequently, there is an urgent need to develop a guide (guide - plan, guide) for the formation of state policy for the development of multimodal transportation by clean and energy efficient vehicles.

\section{Objectives}

The aim of the article is to develop a guide to the formation of state policy for the development of multimodal transportation on the principles of equality of generations to the well-being and safe environment, partnership of generations and their responsibility for the environment.

\section{Materials and methods}

In the course of the research the following methods were used: comparative analysis - in studying the state policies of developed countries with a guide to the formation of state policy for the development of multimodal transportation by clean and energy efficient vehicles; strategic analysis - in assessing the realism of the nationally determined contribution in terms of transport; GAP-analysis - in finding ways to achieve the ambitious goals for the development of multimodal transportation by electric vehicles; abstract-logical - in generalizing the results of the study and formulating conclusions.

\section{Results and discussion}

1. Modern processes of globalization transform the market of transport and logistics services and encourage its players to develop new forms and types of transport, in particular, multimodal transport. Therefore, in order to accelerate their development and ensure full and effective use of the country's transit potential by the National Transport Strategy of Ukraine until 2030, approved by the order of the Cabinet of Ministers of 30.05.2018 for № 430-r (Verkhovna Rada: 30-05-2018, 2018) (hereinafter - the National Transport Strategy) identified the following strategic priorities for the development of multimodal transport, in particular: 
- Improvement of the regulatory framework for the development of multimodal transportation and transport logistics.

- Creation of a network of «dry ports», terminals, specialized transshipment complexes, etc.

- Ensuring unified technological compatibility in the main areas of transportation, etc. (Verkhovna Rada, 2018).

On the other hand, the issue of developing multimodal transport by clean and energy-efficient transport has practically gone unnoticed by government officials. Ukrainian road hauliers for the transportation of goods through the territory of the EU is becoming more difficult every day. Standards for $\mathrm{CO} 2$ emissions from cars are also rising, tax rates on gasoline and diesel are rising, and so on. It is worth remembering the conclusion of the Association Agreement between Ukraine and the European Union, under which Ukraine has committed itself to adapt regulations to EU law, in particular, in terms of «greening» of motor vehicles (Chernyshova et al., 2020).

Understanding the omissions in the National Transport Strategy, to remedy the situation by the Law of Ukraine «On Basic Principles (Strategy) of State Environmental Policy of Ukraine until 2030» of 28.02.2019 for №2697-VIII (Verkhovna Rada: 28-02-2019) in the context of «landscaping» of vehicles provides:

- Reduction in 2030 of emissions of pollutants into the atmosphere from mobile sources, compared to the base 2015 by $30 \%$.

- Increase in the share of electric vehicles in the total number of newly purchased vehicles in 2030 to 10\% (Verkhovna Rada, 2019).

However, to reduce by $30 \%$ emissions of pollutants into the atmosphere from mobile sources, it is necessary that the share of electric vehicles in the structure of vehicles was at least 20-25\% (Chernyshova et al., 2020). Therefore, in order to correctly determine the vectors of the state policy for the development of multimodal transport by clean road transport, we consider it necessary to first of all consider the European policy of multimodal freight transport.

According to the new transport strategy of the European Commission and the Action Plan for the transformation by 2050 of the European transport system to a smart, competitive, sustainable and safe transport system, the European policy of multimodal freight transport is based on the principles of:

- Balancing the interests of stakeholders.

- Commodities. 
Oleksandr Datsii, Nataliia Levchenko, Ganna Shyshkanova, Oleg Platonov y Viktorïa Zalizniuk
888 State policy for the development of multimodal transportation by clean and energy efficient motor transport

- Seamless door-to-door service.

- «Green» cars.

- «Green» transport corridors.

- Locality of «dirty» restrictions.

- «Electronic freight».

- «Electronic transport document».

- «Intelligence of transport systems» etc. (Melnyk, 2020).

In particular, the principle of balancing the interests of stakeholders outlines the interests of present and future generations in a favorable environment. The modality of European policy is to ensure the efficiency of freight through the compatibility of different modes of transport (rail, water, air, road) and the efficiency of transport infrastructure, which combine to create seamless transport corridors with door-to-door service.

The principle of «green cars» (promotion of electric vehicles and scaling of freight with reduced impact of vehicles on the human and natural environment), as well as the principle of «green corridors» (i.e. the creation of integrated routes by combining vehicles with low-carbon two-way transport in seamless service doors ", using, where appropriate, specialized terminals) indicate the intentions of EU countries to make freight more sustainable and environmentally friendly, safe and friendly to consumers and the environment.

Different levels of car congestion and pollution in some areas, encourages more and more EU cities to introduce local regulatory policies, ie to be guided by the principle of locality «dirty» restrictions, which provides or payment for infrastructure depending on direct or indirect environmental standards (eg toll roads), or the arrangement of low emission zones or even a complete ban on the use of cars on diesel and / or gasoline fuel (Chernyshova et al., 2020).

Digitalization of the same multimodal freight involves the use of:

- «Electronic freight», which allows you to track the cargo during its transportation by different modes of transport.

- «Single transport document», which prevents the emergence of regulatory, technical, organizational, financial and other barriers in the movement of goods.

- «Intelligent transport systems» (hereinafter - ITS), which provides the ability to obtain additional data on traffic and predict network efficiency (Melnyk, 2020). 
- Thus, these principles clearly define the purpose of the new transport strategy of the EU - to support global trends in «greening» of freight, and above all, trucking. Currently, many countries around the world have formed state policies for the development of multimodal transportation by «green» cars, as evidenced by Table 1 .

\section{Table 1: Comparative analysis of state policies for the development of freight transportation by clean and energy efficient vehicles (International Energy Agency, IEA, 2021).}

\begin{tabular}{|c|c|c|}
\hline Country & $\begin{array}{l}\text { The content of measures provided by } \\
\text { public policy }\end{array}$ & Ambitious goals \\
\hline EU & $\begin{array}{l}\text { - Directive 2009/33 / EC of the European } \\
\text { Parliament and of the Council of } 23 \text { April } \\
2009 \text { (European Parliament in: https://eur- } \\
\text { lex.europa.eu/legal-content/EN/TXT/? } \\
\text { uri=CELEX\%3A32009L0033.2009) was } \\
\text { revised; } \\
\text { - at the request of the participating countries } \\
\text { (Austria, Belgium, Denmark, Greece, } \\
\text { Ireland, Lithuania, Luxembourg, Malta and } \\
\text { the Netherlands) set a date for the phasing } \\
\text { out of the sale of new cars with gasoline and } \\
\text { diesel engines in the EU; } \\
\text { - a ban from 2030 on the registration of new } \\
\text { cars with internal combustion engines }\end{array}$ & $\begin{array}{l}\text { - reduction of } \\
\text { CO2 emissions in } \\
\text { the field of road } \\
\text { freight transport } \\
\text { by } 20-10 \% \text { by } \\
2030 \text { compared } \\
\text { to the level of } \\
\text { emissions in } 2017 .\end{array}$ \\
\hline Finland & $\begin{array}{l}\text { state support and incentives for the } \\
\text { production of NDV electric vehicles }\end{array}$ & $\begin{array}{l}\text { production by } \\
2030 \text { of } 4600 \\
\text { NDV electric cars }\end{array}$ \\
\hline France & $\begin{array}{l}\text { - ambitious plans for the production of } \\
\text { electric trucks and ways to implement them } \\
\text { have been identified }\end{array}$ & $\begin{array}{l}\text { annual issue } \\
\text { before: } \\
2023 \text { - } 200 \text { FCEV } \\
\text { electric trucks; } \\
2028 \text { - } 800-2000 \\
\text { FCEV electric } \\
\text { trucks. }\end{array}$ \\
\hline Germany & $\begin{array}{l}\text { introduced: } \\
\text { - from November } 5,2019 \text { to December } 31, \\
2025 \text {, the Umweltbonus support program - } \\
\text { an environmental bonus for electric cars; } \\
\text { - by the end of } 2021 \text {, economic incentives to } \\
\text { overcome the effects of COVID-19; } \\
\text { - charging infrastructure program (EUR } 300 \\
\text { million), etc. }\end{array}$ & $\begin{array}{l}\text { ensuring the } \\
\text { registration of } \\
7-10 \text { million } \\
\text { electric vehicles by } \\
2030 \text { in order to } \\
\text { reduce emissions } \\
\text { from the transport } \\
\text { sector by almost } \\
42 \%\end{array}$ \\
\hline Canada & $\begin{array}{l}\text { - agreed the Standard of } \mathrm{CO} 2 \text { emissions from } \\
\text { transport with HBV2 USA }\end{array}$ & $\begin{array}{l}\text { reduction of } \\
\text { CO2 emissions } \\
\text { in the field of } \\
\text { freight transport } \\
\text { by road by } 2027 \\
\text { (depending on } \\
\text { the category and } \\
\text { weight of the } \\
\text { car) by 5-25\% } \\
\text { compared to } 2017 \text {. }\end{array}$ \\
\hline
\end{tabular}


Oleksandr Datsii, Nataliia Levchenko, Ganna Shyshkanova, Oleg Platonov y Viktoriia Zalizniuk State policy for the development of multimodal transportation by clean and energy efficient motor transport

\begin{tabular}{|c|c|c|}
\hline China & $\begin{array}{l}\text { introduced: } \\
\text { - Fuel economy standard (GB 17691-2018. } \\
\text { URL: https://www.transportpolicy.net// } \\
\text { standard/china-light-duty-emissions/); } \\
\text { - when buying electric cars of national and } \\
\text { local incentives; } \\
\text { - exemption of buyers of electric vehicles } \\
\text { from paying consumer tax; } \\
\text { - exemption of buyers of electric vehicles } \\
\text { from 01.09.2014 to } 31.12 .2017 \text { from the } \\
\text { purchase tax; } \\
\text { - reduced registration fee by 50\%, etc. }\end{array}$ & $\begin{array}{l}\text { reduction of fuel } \\
\text { consumption by } \\
14-16 \% \text { compared } \\
\text { to } 2015 .\end{array}$ \\
\hline $\begin{array}{l}\text { South } \\
\text { Korea }\end{array}$ & $\begin{array}{l}\text { introduced: } \\
\text { - measures to stimulate and simplify the } \\
\text { system of taxation of electric car production }\end{array}$ & $\begin{array}{l}\text { production by } \\
2040 \text { up to } 30,000 \\
\text { electric trucks }\end{array}$ \\
\hline Norway & $\begin{array}{l}\text { introduction of measures to stimulate and } \\
\text { simplify the system of taxation of electric car } \\
\text { production: } \\
\text { - zero VAT rate on electric cars; } \\
\text { - exemption from purchase tax; } \\
\text { - exemption from road insurance; } \\
\text { - 50\% of the toll; } \\
\text { - - 50\% of the parking fee }\end{array}$ & $\begin{array}{l}\text { increase by } 2030 \\
\text { the share of } \\
\text { electric trucks (up } \\
\text { to } 50 \% \text { ) in the } \\
\text { total volume of } \\
\text { truck production }\end{array}$ \\
\hline USA & $\begin{array}{l}\text { introduced: } \\
\text { - 10 million dollars. for research, } \\
\text { development and demonstration of } \\
\text { innovative technologies and designs; } \\
-\$ 20 \text { million to accelerate the introduction } \\
\text { of affordable electric vehicles (plug-in electric } \\
\text { vehicles - PEV) }\end{array}$ & $\begin{array}{l}\text { creation by } 2030 \\
\text { of a national } \\
\text { network of } 500 \\
\text { thousand chargers } \\
\text { for electric } \\
\text { vehicles }\end{array}$ \\
\hline Japan & $\begin{array}{l}\text { introduced: } \\
\text { - Fuel economy standard: } 6.52-7.63 \mathrm{~km} / 1 \\
\text { for heavy commercial vehicles (depending on } \\
\text { the class and weight of the vehicle) }\end{array}$ & $\begin{array}{l}\text { reduction of fuel } \\
\text { consumption } \\
\text { by } 13.4-14 \cdot 3 \% \\
\text { compared to } 2015 \\
\end{array}$ \\
\hline
\end{tabular}

Subject to the implementation by the EU countries of the multimodal transport policies listed in Table 1, Ukrainian carriers will be gradually displaced from the European market. Therefore, the Government of Ukraine should immediately decide on the state policy for the development of multimodal transportation by clean vehicles, its priority vectors and ways of implementation.

At present, the Ministry of Infrastructure of Ukraine, in close cooperation with other ministries, has taken the first steps towards the promotion of electric vehicles and whether they are effective and truly efficient remains an open question. So, let's take a brief look at some of them.

Thus, the Law of Ukraine №3476 «On Amendments to the Tax Code of Ukraine and Certain Legislative Acts of Ukraine on Stimulating the Development of the Electric Transport Sector in Ukraine» of 14.05.2020 under №3476 (Verkhovna Rada, 2020) (hereinafter - the Law of Ukraine №3476) and the Law of Ukraine "On Amendments to the Customs Code of 
Ukraine to stimulate the development of the electric transport industry in Ukraine" dated 14.05.2020 by 773477 (Verkhovna Rada, 2020) (hereinafter - the Law of Ukraine №3477) provides for amendments to the Tax Code of Ukraine (Verkhovna Rada, 2010) and Of the Customs Code of Ukraine (Verkhovna Rada, 2012) to create favorable conditions for attracting investment in the production of electric vehicles, chargers, accessories products to them, as well as stimulating the demand for cars and trucks equipped exclusively with electric motors (Verkhovna Rada, 2020).

According to the mentioned legislative acts, a temporary exemption from VAT and income tax on transactions is provided, the list of which is given in Fig.1.

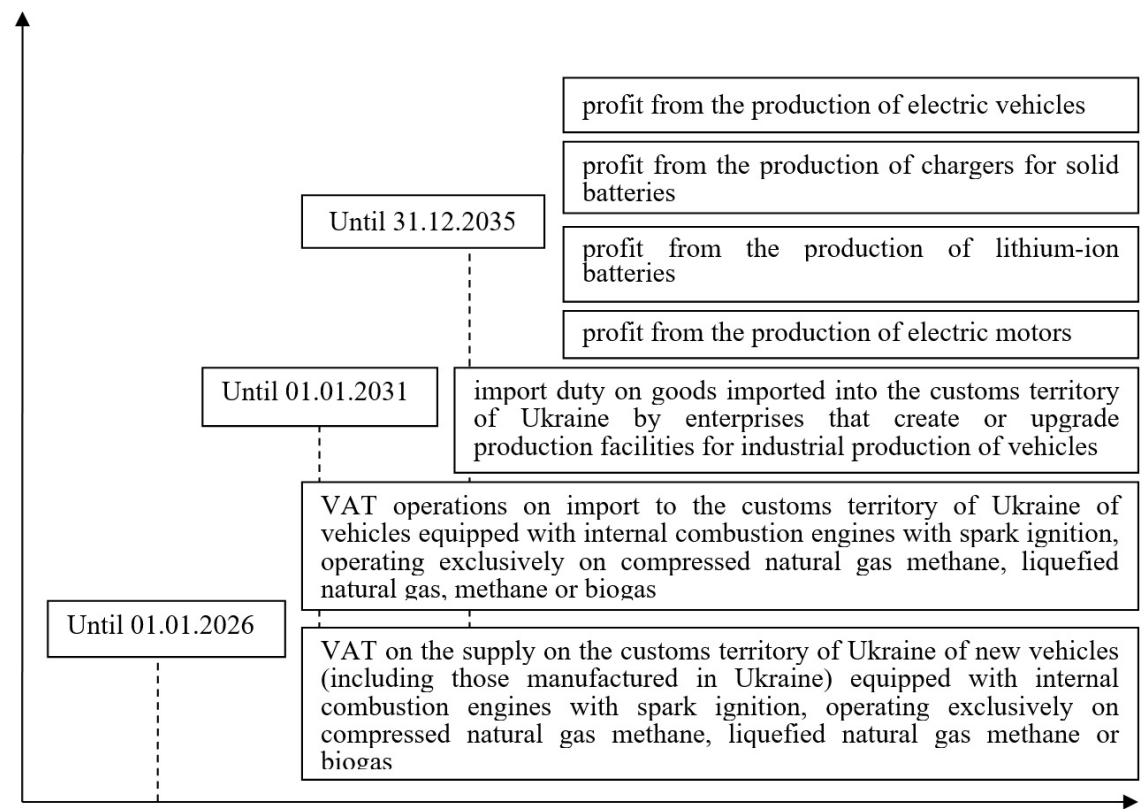

\section{Fig.1. Measures to stimulate the promotion of clean and energy efficient transport in Ukraine, defined by the Law of Ukraine №3476 (Verkhovna Rada, 2020).}

Instead, funds were released (as a result of tax exemption) according to paragraph 2 of Article 1 of the Law of Ukraine №3476 (Verkhovna Rada, 2020) is recognized as targeted funding and therefore they can be used by taxpayers (eligible for tax exemption) only for research and development 
Oleksandr Datsii, Nataliia Levchenko, Ganna Shyshkanova, Oleg Platonov y Viktoriia Zalizniuk State policy for the development of multimodal transportation by clean and energy efficient motor transport

work in the field of electric transport, creation or re-equipment of material and technical base, increase volume of production and introduction of new technologies (Verkhovna Rada, 2020).

The Draft Law of Ukraine "On Amendments to the Law of Ukraine" On Road Transport "dated 05.04.2001 under №2344-III (Verkhovna Rada, 2001) to stimulate the use of vehicles equipped with electric motors «, is also designed to stimulate the promotion of vehicles equipped with electric motors.

The Concept of implementation of the state policy in the field of development of infrastructure of charging stations for electric vehicles (further - the Concept) is not deprived of measures of stimulation (BRDO, 2018), developed by the Directorate of State Policy in the Field of Digital Infrastructure for Transport and Postal Services of the Ministry of Infrastructure of Ukraine in close cooperation with the Better Regulation Delivery Office, Of course we already have some results. Thus, if according to the marketing agency IRS Group, in September 2020 in Ukraine there were 8529 points of charging stations, during the year their number increased by more than half (Eu4business, 2021). Instead, to achieve this goal - to increase the share of electric vehicles in the structure of vehicles, such a pace of development of charging stations is significantly insufficient.

The list of steps taken by the government to develop multimodal clean road transport can be continued, but each is fragmentary and focused only on stimulating the promotion of electric vehicles. With such a regulatory policy to achieve in the near future the goal of «greening» vehicles and defined in the Law of Ukraine №2697-VIII (Verkhovna Rada, 2019) reducing emissions of pollutants from mobile sources is quite difficult. Therefore, we have every reason to say that Ukraine still lacks a balanced state policy for the development of multimodal transportation by clean and energy efficient vehicles. We consider it expedient to start its formation with the development of a guide, ie a guide with a clear definition of the etapology and sequence of actions.

And its development should begin with the definition of strategic imperatives - mandatory framework goals of strategies, which are determined by the current state of the national transport system, current risks and challenges, needs and expectations of stakeholders. Therefore, the initial stage of developing a policy of multimodal freight transport by clean vehicles should be a stakeholder analysis, which will include collecting information on stakeholders, prioritizing them, studying the interests of «greening» transportation and the possibility of balancing them.

The next step should be to study the transit potential of the country and prospects for its development. It should be noted that according to the decision of the II Pan-European Conference of Ministers of Transport 
of European countries, the network of international transport corridors (hereinafter - ITC) includes the following transport corridors passing through the territory of Ukraine (Table 2).

\section{Table 2: International Road transport corridors passing through the territory of Ukraine (Ministry of Infrastructure of Ukraine, 2021)}

\begin{tabular}{|c|c|c|c|}
\hline $\begin{array}{l}\text { Name of the } \\
\text { international } \\
\text { transport corridor }\end{array}$ & Itinerary & $\begin{array}{l}\text { Countries- } \\
\text { members }\end{array}$ & $\begin{array}{l}\text { The length of } \\
\text { the main course } \\
\text { by road, km }\end{array}$ \\
\hline $\begin{array}{l}\text { Pan-European } \\
\text { Transport Corridor } \\
\text { №3 (Cretan №3) }\end{array}$ & $\begin{array}{l}\text { Berlin (Dresden) - } \\
\text { Wroclaw-Lviv-Kyiv) }\end{array}$ & $\begin{array}{l}\text { Germany, } \\
\text { Poland, } \\
\text { Ukraine }\end{array}$ & 611,7 \\
\hline $\begin{array}{l}\text { Pan-European } \\
\text { Transport Corridor } \\
\text { №5 (Cretan №5) }\end{array}$ & $\begin{array}{l}\text { Trieste-Ljubljana- } \\
\text { Budapest-Bratislava- } \\
\text { Uzhhorod-Lviv }\end{array}$ & $\begin{array}{l}\text { Italy, } \\
\text { Slovenia, } \\
\text { Hungary, } \\
\text { Slovakia, } \\
\text { Ukraine }\end{array}$ & 338,7 \\
\hline $\begin{array}{l}\text { Pan-European } \\
\text { Transport Corridor } \\
\text { №9 (Cretan №9) }\end{array}$ & $\begin{array}{l}\text { Helsinki - St. } \\
\text { Petersburg - Vitebsk } \\
\text { - Kyiv - Odessa - } \\
\text { Plovdiv - Bucharest - } \\
\text { Alexandropolis (with } \\
\text { four branches) }\end{array}$ & $\begin{array}{l}\text { Finland, } \\
\text { Ukraine, } \\
\text { Belarus, } \\
\text { Moldova, } \\
\text { Romania, } \\
\text { Greece }\end{array}$ & 996,1 \\
\hline $\begin{array}{l}\text { Europe - Caucasus } \\
\text { - Asia (TRACECA) } \\
\text { Europe-Asia }\end{array}$ & $\begin{array}{l}\text { Krakivets-Lviv-Rivne- } \\
\text { Zhytomyr-Kyiv- } \\
\text { Poltava-Kharkiv- } \\
\text { Debaltsovo-Izvaryne }\end{array}$ & $\begin{array}{l}\text { Europe, } \\
\text { Georgia, } \\
\text { Ukraine }\end{array}$ & 712,3 \\
\hline $\begin{array}{l}\text { Gdansk-Odessa } \\
\text { (Baltic Sea-Black Sea) }\end{array}$ & $\begin{array}{l}\text { Yahodyn-Kovel- } \\
\text { Lutsk-Ternopil- } \\
\text { Khmelnytskyi- } \\
\text { Vinnytsia-Uman- } \\
\text { Odessa / Ilchivsk } \\
\end{array}$ & $\begin{array}{l}\text { Poland, } \\
\text { Ukraine }\end{array}$ & 1208,4 \\
\hline
\end{tabular}

Therefore, the Ministry of Infrastructure of Ukraine, realizing the transit potential of the country, sees an ambitious goal in the near future - its full implementation and thus transforming Ukraine into the main transit country of the Eurasian continent with the most comfortable conditions for transportation in Europe-Asia and reliable international partner. logistics services on the continent (Ministry of Infrastructure of Ukraine, 2018).

With information on the country's transit potential and opportunities to increase the volume of multimodal road transport, it is impossible to avoid the study of the car fleet. Therefore, the next stage in the formation of a policy for the development of multimodal transportation should be a study of vehicles by age and technical condition, the need for renewal, the type of fuel used, compliance with environmental norms and standards, and so on. 
Oleksandr Datsii, Nataliia Levchenko, Ganna Shyshkanova, Oleg Platonov y Viktorïa Zalizniuk
894 State policy for the development of multimodal transportation by clean and energy efficient motor transport

In particular, according to IAG AUTO Consulting, the car fleet of Ukraine, as of January 1, 2019, amounted to more than 10 million cars. At the same time, the average age of cars in Ukraine is about 21.5 years. For comparison, the average age of cars in the EU is 10.5 years, in Germany - 9.3, in Poland 13.6 years. More than 50\% of Ukraine's car fleet was produced before 1991, when Europe first introduced the EURO-O environmental standards and from which the regulation of vehicle emissions began. In the future, almost every 5 years, the requirements for environmental standards of vehicles were strengthened until in 2014, the adoption of EURO-6 (Chernyshova et al., 2020) (Table 3).

\section{Table 3. EURO environmental standards for regulating the level of emissions of hazardous substances from cars (Chernyshova et al., 2020).}

\begin{tabular}{|c|c|c|c|c|c|c|c|}
\hline \multicolumn{3}{|c|}{ Introduction date } & \multicolumn{2}{c|}{ Gasoline } & \multicolumn{2}{c|}{ Diesel } & $\begin{array}{c}\text { Gasoline } \\
\text { and diesel }\end{array}$ \\
\hline $\begin{array}{c}\text { Euro } \\
\text { standard }\end{array}$ & $\begin{array}{c}\text { New } \\
\text { certifications }\end{array}$ & $\begin{array}{c}\text { All new } \\
\text { registrations }\end{array}$ & $\begin{array}{c}\text { Nox } \\
(\mathrm{g} / \mathrm{km})\end{array}$ & $\begin{array}{c}\text { Particle } \\
\text { mass } \\
(\mathrm{g} / \mathrm{km})\end{array}$ & $\begin{array}{c}\text { Nox } \\
(\mathrm{r} / \\
\mathrm{KM})\end{array}$ & $\begin{array}{c}\text { Particle } \\
\text { mass } \\
(\mathrm{g} / \mathrm{km})\end{array}$ & $\begin{array}{c}\text { The number } \\
\text { of fine } \\
\text { particles per } \\
\mathrm{km}\end{array}$ \\
\hline EURO-1 & 01.06 .1992 & 31.12 .1992 & $0,97^{(1)}$ & - & $0,97^{(1)}$ & 0,14 & - \\
\hline EURO-2 & 01.01 .1996 & 01.01 .1997 & $0,5^{(1)}$ & - & $0,9^{(1)}$ & 0,1 & - \\
\hline EURO-3 & 01.01 .2000 & 01.01 .2001 & 0,15 & - & 0,5 & 0,05 & - \\
\hline EURO-4 & 01.01 .2005 & 01.01 .2006 & 0,08 & - & 0,25 & 0,025 & - \\
\hline EURO-5 & 01.09 .2009 & 01.01 .2011 & 0,06 & $0,0045^{(2)}$ & 0,18 & 0,0045 & $6 \times 1011^{(3)}$ \\
\hline EURO-6 & 01.09 .2014 & 01.09 .2015 & 0,06 & $0,0045^{(2)}$ & 0,08 & 0,0045 & $6 \times 1011^{(4)(5)}$ \\
\hline
\end{tabular}

(1) Expressed as $\mathrm{HC}+\mathrm{NOx}$

(2) Applies to gasoline direct injection engines

(3) Applies to diesel engines only

(4) Within $6 \times 1011$ in the case of direct injection petrol engines

(5) General limits $6 \times 1011$ for gasoline direct injection engines and diesel engines starting from September 2017 / September 2018 (Chernyshova et al., 2020).

On the other hand, the share of cars that meet the EURO- 5 and EURO- 6 standards in Ukraine so far fluctuates only within 5-6\% (Chernyshova et al., 2020). Thus, while Europe is actively working to update the requirements and technological solutions for «greening» cars, Ukraine continues to be filled with old vehicles from EU countries. Regarding the distribution by type of fuel, it should be noted that among the 496.5 thousand cars registered in 2019 , more than 50\% are equipped with diesel engines (of which more than $88 \%$ - second-hand), gasoline cars accounted for $38 \%$ of registered and $8 \%$ - cars with gas cylinder equipment. Hybrid cars accounted for almost $2 \%$ of 
those registered, and electric-powered cars accounted for barely $1 \%$ of the primary market (Chernyshova et al., 2020).

The unregulated standardization of motor transport and the lack of a state policy for the development of freight transport by clean motor transport have caused Ukraine to constantly become a reserve for used environmentally friendly cars from abroad (Chernyshova et al., 2020), which leads to environmental pollution due to significant gases. Therefore, the next stage in the development of state policy for the development of multimodal transport by clean vehicles should be to study the dynamics of greenhouse gas emissions by vehicles, study forecasts of their changes with increasing freight and conduct a comparative analysis with indicators of the Second National Contribution of Ukraine to the Paris Agreement. .

Thus, according to the Annual National Inventory Report for Submission under the United Nations Framework Convention on Climate Change and the Kyoto Protocol «UKRAINE'S GREENHOUSE GAS INVENTORY 19902019» (Ministry of Environmental Protection and Natural Resources of Ukraine, in: https: // unfccc .int / documents / 273676, 2020), prepared by the Ministry of Environmental Protection and Natural Resources of Ukraine, the volume of greenhouse gas emissions by vehicles during 19902020 is characterized by the data presented in table. 4 .

Table 4: Volumes of greenhouse gas emissions by vehicles of Ukraine during 1990-2019, mln tons of CO2-eq. (Ministry of Environmental Protection and Natural Resources of Ukraine, 2020).

\begin{tabular}{|c|c|c|c|c|c|c|c|}
\hline \multirow[b]{3}{*}{$\begin{array}{l}\text { Emission } \\
\text { category }\end{array}$} & \multirow{3}{*}{$\begin{array}{c}\mathrm{CO} 2 \\
\text { emissions } \\
\text { in Ukraine } \\
\text { as a whole }\end{array}$} & \multicolumn{6}{|c|}{ Among them Transport } \\
\hline & & \multirow[b]{2}{*}{$\begin{array}{c}\text { 1.A.3 } \\
\text { Transport } \\
\text { total, } \\
\text { including: }\end{array}$} & \multicolumn{5}{|c|}{ Including } \\
\hline & & & $\begin{array}{l}\text { 1.A.3.a } \\
\text { Civil } \\
\text { Aviation }\end{array}$ & $\begin{array}{c}\text { 1.A.3.b } \\
\text { Road } \\
\text { Transport }\end{array}$ & $\begin{array}{c}\text { 1.A.3.c } \\
\text { Railways }\end{array}$ & $\begin{array}{c}\text { 1.A.3.d } \\
\text { Water-way } \\
\text { Transport }\end{array}$ & $\begin{array}{l}\text { 1.A.3.e } \\
\text { Other } \\
\text { types of } \\
\text { transport }\end{array}$ \\
\hline 1990 & 705.8 & 111.79 & 0.68 & 61.37 & 3.83 & 3.27 & 42.64 \\
\hline 1995 & 389.9 & 49.22 & 0.11 & 20.73 & 1.32 & 0.43 & 26.63 \\
\hline 2000 & 285.3 & 34.55 & 0.07 & 15.78 & 1.39 & 0.20 & 17.12 \\
\hline 2005 & 313,1 & 39.19 & 0.20 & 22.16 & 0.88 & 0.20 & 15.75 \\
\hline 2010 & 294.1 & 40.20 & 0.17 & 28.89 & 0.55 & 0.10 & 10.49 \\
\hline 2011 & 308.0 & 40.29 & 0.18 & 28.38 & 0.53 & 0.08 & 11.12 \\
\hline 2012 & 304.0 & 39.36 & 0,20 & 29.10 & 0.38 & 0.08 & 9.60 \\
\hline 2013 & 297.2 & 39.51 & 0,17 & 28.86 & 0.44 & 0.05 & 10.00 \\
\hline 2014 & 257.5 & 3.5 .89 & 0,09 & 26.73 & 0.45 & 0.06 & 8.5 .5 \\
\hline 2015 & 223.8 & 31.10 & 0,08 & 22.81 & 0.45 & 0.08 & 7.68 \\
\hline 2016 & 234,0 & 32.89 & 0,13 & 23.96 & 0.47 & 0.08 & 8.24 \\
\hline 2017 & 223.1 & 34.94 & 0,17 & 24.68 & 0.56 & 0.08 & 9.45 \\
\hline 2018 & 232.0 & 34.96 & 0,17 & 24,72 & 0,57 & 0.08 & 9,41 \\
\hline 2019 & 222.6 & 37.73 & 0,18 & 26,65 & 0,59 & 0.08 & 10,23 \\
\hline
\end{tabular}


Greenhouse gas emissions in 2019 amounted to 26.65 million tons of CO2-eq., Increasing compared to the base year 2015 (as defined by the Law of Ukraine №2697-VIII), by 16.8\%, which we can clearly see in Fig. 2.

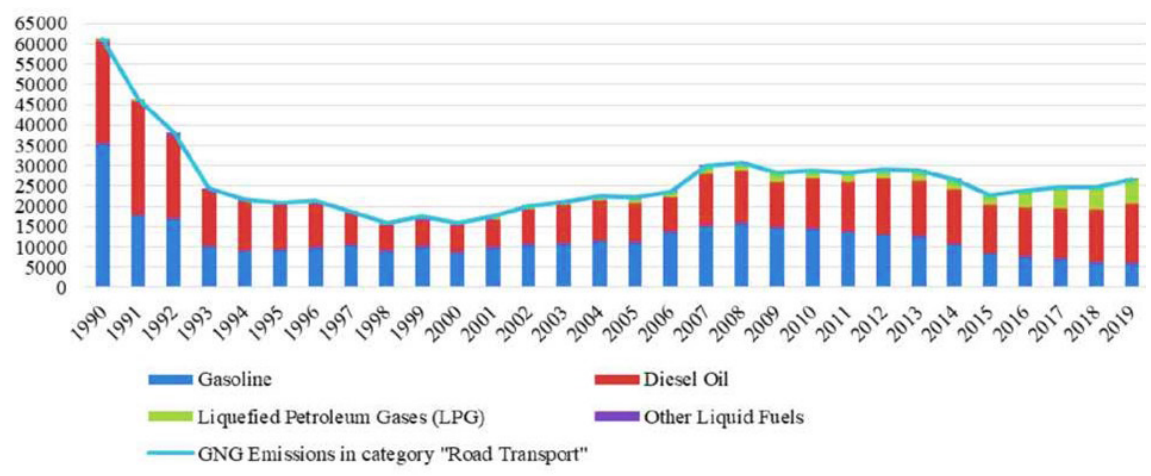

Fig. 2: GHG emissions in category 1.A.3.b "Road Transport" by fuels, for 1990-2019, kt of CO2-eq. (Ministry of Environmental Protection and Natural Resources of Ukraine, 2020)

We emphasize that according to the indicators of HBV2, Ukraine has committed to reduce emissions of pollutants into the atmosphere from mobile sources by 2030, compared to the base 2015 by 30\%. Therefore, based on the expected reduction of greenhouse gas emissions by vehicles, a model for achieving this goal should be clearly defined: accelerated import of electric vehicles (import-dependent), establishment of own production of electric vehicles (own production) or mixed model, which provides .

Regarding the import-dependent model of implementation of the state policy of development of multimodal transport by clean motor transport, it should be noted that the Laws of Ukraine №3476 and №3477 provide for measures to stimulate demand for cars equipped exclusively with electric motors. However, we note that despite the steady increase in the number of electric cars in Ukraine, their share is growing steadily due to the growth of imports of used cars. Thus, in 2019, 7,542 units of vehicles operating exclusively on electric traction were registered in Ukraine.

However, among them continue to dominate electric cars (namely 93\%) with mileage. At the same time, the average age of an electric second-hand car registered in Ukraine in 2019 is four years. Since most manufacturers guarantee battery life for up to 8 years, we have reason to believe that almost half of electric vehicles are already on the verge of battery use (Chernyshova et al., 2020). The purchase of new electric cars is significantly complicated 
by high prices and low solvency of Ukrainian buyers. Thus, we come to the conclusion that the choice of «import-dependent» model is impractical.

The choice of the "own production» model should be determined by the technological capability and readiness of the machine-building industry of Ukraine for the production of electric vehicles. Thus, when choosing the model of «own production» the next step in the formation of state policy for the development of multimodal transport by clean vehicles should be to study the state of the machine building industry and its readiness for technological change, determine the potential volume, type and sources of funding - whether national and / or international.

According to the latest research, the engineering industry in Ukraine is in decline, so its recovery and modernization requires some time, the loss of which Ukraine can not afford. Therefore, with the establishment of its own production of clean and energy efficient transport, measures should be taken simultaneously to update the fleet, namely the modernization of vehicles, replacement of the traction source and so on. An example of this is the programs of renewal (replacement) of obsolete vehicles, which have become widespread in world practice (Table 5).

\section{Table 5: Programs for renewal (replacement) of obsolete vehicles that have become widespread in world practice \\ (Chernyshova et al., 2020)}

\begin{tabular}{|c|c|c|c|}
\hline Program & Vehicles covered & $\begin{array}{c}\text { Approximate size } \\
\text { of the average } \\
\text { subsidy }\end{array}$ & $\begin{array}{l}\text { Additional programs } \\
\text { that were used for } \\
\text { amplification }\end{array}$ \\
\hline $\begin{array}{l}\text { USA: Carl } \\
\text { Moyer } \\
\text { Program } \\
\text { (California) }\end{array}$ & $\begin{array}{l}\text { various vehicle } \\
\text { types, including } \\
\text { non-road } \\
\text { infrastructure }\end{array}$ & $\begin{array}{l}\$ 28 \text { ooo on } \\
\text { vehicle }\end{array}$ & $\begin{array}{l}\text { mandatory } \\
\text { modernization of } \\
\text { vehicles with a high } \\
\text { level of pollution }\end{array}$ \\
\hline $\begin{array}{l}\text { USA: National } \\
\text { Clean Diesel } \\
\text { Campaign } \\
\text { (CARS) }\end{array}$ & trucks & $\$ 9400$ on vehicle & no \\
\hline $\begin{array}{l}\text { China: } \\
\text { National } \\
\text { Vehicle } \\
\text { Recycling } \\
\text { Program }\end{array}$ & cars and trucks & $\begin{array}{l}\text { depends on the } \\
\text { type of vehicle: } \\
\text { from } \$ 980 \text { to } \$ \\
2940\end{array}$ & $\begin{array}{l}\text { mandatory limit on } \\
\text { the maximum age of } \\
\text { the car }\end{array}$ \\
\hline $\begin{array}{l}\text { China: local } \\
\text { vehicle } \\
\text { recycling } \\
\text { program }\end{array}$ & cars and trucks & $\begin{array}{l}\text { depends on the } \\
\text { type of vehicle: } \\
\text { cars } \$ 410-\$ \\
2410 \text {; trucks: } \$ \\
1330-\$ 2100\end{array}$ & $\begin{array}{l}\text { mandatory limit on } \\
\text { the maximum age of } \\
\text { the car }\end{array}$ \\
\hline
\end{tabular}


Oleksandr Datsii, Nataliia Levchenko, Ganna Shyshkanova, Oleg Platonov y Viktoriia Zalizniuk State policy for the development of multimodal transportation by clean and energy efficient motor transport

\begin{tabular}{|l|l|l|l|}
\hline $\begin{array}{l}\text { Mexico: } \\
\text { Federal Land } \\
\begin{array}{l}\text { Transport } \\
\text { Modernization } \\
\text { Program }\end{array}\end{array}$ & $\begin{array}{l}\text { trucks on federal } \\
\text { highways }\end{array}$ & $\begin{array}{l}\text { up to 15\% of the } \\
\text { cost of vehicle } \\
\text { replacement }\end{array}$ & no \\
\hline $\begin{array}{l}\text { Chile: } \\
\text { Exchange your } \\
\text { truck }\end{array}$ & trucks & $\begin{array}{l}\text { from } \$ \text { 8,ooo to } \$ \\
\text { 24,000 depending } \\
\text { on the category of } \\
\text { vehicle }\end{array}$ & $\begin{array}{l}\text { partially: a } \\
\text { decree on the } \\
\text { implementation of a } \\
\text { low-emission zone. }\end{array}$ \\
\hline
\end{tabular}

It should be noted that the procedure for updating vehicles should be both voluntary (for cars with low levels of environmental pollution) and compulsory (for cars with medium and high levels of environmental pollution). This, in turn, requires the full implementation in domestic practice of European standards for emissions of pollutants by cars and, accordingly, the organization of control over their emissions.

Of course, the model of "own production" is the most desirable, but its introduction in the disastrous state of the engineering industry requires significant investment. Investors today prefer ESG-investing. Instead, most machine-building enterprises of Ukraine do not meet the ESG criteria. Therefore, it is quite risky to expect the desired amount of investment. Lending by international development banks also requires compliance with certain requirements: the creation of an appropriate legal, institutional and favorable investment environment; state guarantee of repayment of international loans, etc. The measures taken by the Government of Ukraine to comply with these requirements are currently insufficient. Consequently, the introduction of the "own production» model is complicated by the lack of adequate financial support.

Therefore, the most optimistic for the introduction in Ukraine at the present stage we consider a «mixed» model, which provides for the establishment of its own production with the simultaneous import of electric vehicles. The implementation of such a policy will provide a comprehensive approach to accelerating the transition to mass use of clean and energy efficient vehicles (BRDO, 2018).

Instead, the validity of the choice of a model for the implementation of state policy for the development of multimodal transportation by clean vehicles requires the calculation of not only the amount of investment but also the effectiveness of public policy. Since Ukraine has implemented the Sustainable Development Goals, when assessing the effectiveness of the state policy for the development of multimodal transportation by clean vehicles, the expected environmental, social and economic effects should be assessed. It is also important to keep in mind the need to study possible risks and threats, as well as to identify ways to prevent or minimize them. Therefore, only if you are confident in achieving these effects and successful 
implementation, the state policy for the development of multimodal transportation by clean vehicles should be implemented.

Thus, the author's guide to the formation of state policy for the development of multimodal transportation by clean vehicles acquires the following schematic image, presented in Fig. 3.

definition of obligatory framework goals of strategies, which are determined by the current state of the national transport system, current risks and challenges, needs and expectations of stakeholders

implementation of stakeholder analysis

C collection of information on stakeholders prioritization of stakeholders study of interests in "greening"

transportation and the possibility of balancing them

study of the transit potential of the country and prospects for its development

study of possibilities of increasing volumes of multimodal transportations by motor transport

study of vehicles by age and technical condition, the need for renewal, type of fuel used, compliance with environmental norms and standards

study of the dynamics of greenhouse gas emissions by motor vehicles, study of forecasts of their changes with increasing volumes of freight traffic and implementation of comparative analysis with $\mathrm{HBB} 2$ indicators

determination of the state of standardization of motor transport

choice of the model of realization of the state policy of development of multimodal transportations by pure motor transport

determining the need for investment and sources of funding for the implementation of state policy for the development of multimodal transportation by clean vehicles

assessment of the expected expected ecological, social and economic effect

assessment of risks and threats, identification of ways to prevent or minimize them

introduction of the state policy of development of multimodal transportations by clean and energy-efficient motor transport

Fig. 3: Guide to the formation of state policy for the development of multimodal transportation by clean vehicles (author's development) 
Oleksandr Datsii, Nataliia Levchenko, Ganna Shyshkanova, Oleg Platonov y Viktoriia Zalizniuk State policy for the development of multimodal transportation by clean and energy efficient motor transport

The state policy of developing multimodal transportation by clean and energy-efficient transport formed in this way will ensure environmental protection, fulfillment of Ukraine's commitments on HBV2 and balancing the interests of present and future generations in a favorable environment.

\section{Conclusion}

The above proves that with the intensification of Ukraine's integration into the European and world space, the development of multimodal transportation is gaining momentum. Instead, in order to maintain such trends in the future, many urgent issues need to be addressed, and first of all, the issue of forming a state policy for the development of multimodal transportation by clean and energy-efficient vehicles.

It is proved that the formation of a balanced state policy for the development of multimodal transportation by clean and energy efficient vehicles is possible only with a clear understanding of the challenges facing Ukrainian carriers, their critical understanding and understanding of the possibilities of their prevention or minimization. It is substantiated that the formation of state policy for the development of multimodal transportation by clean and energy efficient vehicles should be carried out with a clear definition of the stage and sequence of actions, ie in accordance with the guide for the formation of state policy. The author's guide on the formation of state policy for the development of multimodal transportation by clean and energy efficient vehicles, aimed at protecting the environment and ensuring the interests of present and future generations in a favorable environment.

\section{Bibliographic References}

EUROPEAN CLIMATE LAW. 2018. Available online. In: https://ec.europa. eu/clima/policies/eu-climate-action/law_en. Consultation date: 08/06/2021.

ON APPROVAL OF THE NATIONAL TRANSPORT STRATEGY OF UKRAINE FOR THE PERIOD UP TO 2030. 2018. May 30. №430-r. Available online. In: https://zakon.rada.gov.ua/laws/show/430-2018\%D1\%80\#Text. Consultation date: 25/04/2021.

CHERNYSHOVA, Elena; PETRENKO, Igor; VYSHEBABA, Paul. 2020. Ecological and transport problems of modern Ukraine. Available online. In: http://icps.com.ua/assets/uploads/images/files/ecology_a4_ukr. pdf. Consultation date: 28/04/2021. 
ONTHEBASICPRINCIPLES(STRATEGY)OFTHESTATEENVIRONMENTAL POLICY OF UKRAINE FOR THE PERIOD UP TO 2030. 2019. February 28, №2697-VIII. Available online. In: https://zakon.rada.gov.ua/laws/ show/2697-19\#Text. Consultation date: 30/04/2021.

MELNYK, Zoya. 2021. What is happening with transportation in the EU and how to adapt to our companies. Available online. In: https://mintrans. news/logistics/shcho-vidbuvaetsya-z-perevezennyami-u-es-ta-yakadaptuvatisya-nashim-kompaniyam. Consultation date: 18/04/2021.

GLOBAL EV POLICY EXPLORER. 2021. Electric vehicle deployment policies and measures. International 2021. Available online. In: https://www.iea. org/articles/global-ev-policy-explorer. Consultation date: 18/04/2021.

ON THE PROMOTION OF ENVIRONMENTALLY FRIENDLY AND ENERGY EFFICIENT VEHICLES. 2009. Directive of the European Parliament and of the Council 2009/33 / EC. 2009. Available online. In: https://eurlex.europa.eu/legal-content/EN/TXT/?uri=CELEX\%3A32009Loo33. Consultation date: 18/04/2021.

STATE STANDARD FOR AUTOMOBILE EMISSIONS «CHINA-VI». 2018. GB 17691-2018. Available online. In: https://www.transportpolicy.net/ standard/china-light-duty-emissions/. Consultation date: 18/04/2021.

ON AMENDMENTS TO THE TAX CODE OF UKRAINE AND SOME LEGISLATIVE ACTS OF UKRAINE TO STIMULATE THE DEVELOPMENT OF THE ELECTRIC TRANSPORT INDUSTRY IN UKRAINE. 2020. May 14. №3476. Available online. In: https://w1.c1. rada.gov.ua/pls/zweb2/webproc4_1?pf3511=68837. Consultation date: 23/06/2021.

ONAMENDMENTSTOTHECUSTOMSCODEOFUKRAINETOSTIMULATE THE DEVELOPMENT OF THE ELECTRIC TRANSPORT INDUSTRY IN UKRAINE. 2020. May 14. №3477. Available online. In: https:// w1.c1.rada.gov.ua/pls/zweb2/webproc4_1?pf3511=68838. Consultation date: 19/06/2021.

TAX CODE OF UKRAINE. 2010. December 2. №2755-VI. Available online. In: https://zakon.rada.gov.ua/laws/show/2755-17. Consultation date: 22/06/2021.

CUSTOMS CODE OF UKRAINE. 2012. March 13. №4495-VI. Available online. In: https://zakon.rada.gov.ua/laws/show/4495-17\#Text. Consultation date: $28 / 06 / 2021$. 
Oleksandr Datsii, Nataliia Levchenko, Ganna Shyshkanova, Oleg Platonov y Viktoriia Zalizniuk

ABOUT MOTOR TRANSPORT. 2001. April 05. №2344-III. Available online. In: https://zakon.rada.gov.ua/laws/show/2344-14\#Text. Consultation date: 19/06/2021.

THE CONCEPT OF IMPLEMENTATION OF STATE POLICY IN THE FIELD OF INFRASTRUCTURE DEVELOPMENT OF CHARGING STATIONS FOR ELECTRIC VEHICLES. 2018. Available online. In: https://drive. google.com/drive/u/1/folders/1ra6dUx93rgnHsAsaN1jMiysTs6aXtS BG Consultation date: 22/06/2021.

INFRASTRUCTURE DEVELOPMENT FOR ELECTRIC VEHICLES. 2021. Eu4business Available online. In: https://eu4business.org.ua/successstories/developing-the-infrastructure-for-electric-cars/. Consultation date: 07/07/2021.

TRANSIT OPPORTUNITIES OF UKRAINE. 2018. Available online. In: https://mtu.gov.ua/content/tmu.html. Consultation date: 02/08/2021.

UKRAINE'S GREENHOUSE GAS INVENTORY 1990-2019. 2019. Annual National Inventory Report for Submission under the United Nations Framework Convention on Climate Change and the Kyoto Protocol. Ministry of Environmental Protection and Natural Resources of Ukraine. Available online. In: https://unfccc.int/documents/273676. Consultation date: 28/07/2021. 

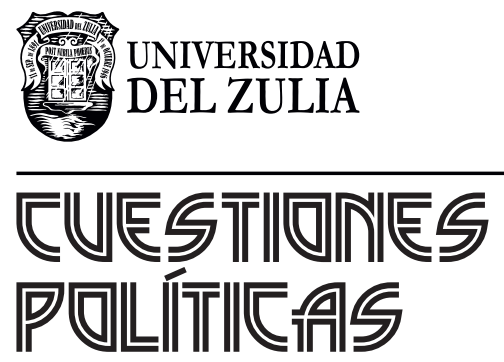

Vol. 39 N $^{\circ} 71$

Esta revista fue editada en formato digital y publicada en diciembre de 2021, por el Fondo Editorial Serbiluz, Universidad del Zulia. Maracaibo-Venezuela 